\title{
Predation by "shooting" in archer fish, Toxotes jaculatrix: Accuracy and sequences
}

\author{
MARC BEKOFF and ROBERT DORR \\ University of Colorado, Department of Environmental, Population, and Organismic Biology \\ Ethology Group, Boulder, Colorado 80309
}

\begin{abstract}
Four adult shooting archer fish (Toxotes jaculatrix) were studied in a captive situation. The accuracy with which they "shot" for prey and the sequences that they performed during shooting were analyzed. The animals were successful in shooting at suspended prey $25.5 \%$ of the time. Shooting was preceded by a series of six acts. The "typical" sequence, based on an analysis of transition probabilities was: Orient, Swim, Rotate Vertically, Shoot. Leaping out of the water and a second vertical rotation were observed also.
\end{abstract}

One way that the archer fish obtains food is to eject a stream of water out of its mouth (hereafter called "shooting") by compressing its gills. Some aspects of this behavior including its evolution and the unique anatomy of the archer have been described by Smith (1938, 1945), Lüling $(1958,1963)$ and Alcock (1972). We undertook this study to determine the accuracy with which four adult archers (known shooters of approximately 1 year of age) could shoot, and to describe the behavioral sequences that culminate in shooting. Smith (1945) wrote that "the distance within which the fish could always be depended on to score a direct hit was $31 / 2-4 \mathrm{ft}$." Herald (1965) suggested that archers are not as accurate as thought to be, but reported no data. Knowledge of the "typical" adult sequence would be important in understanding the ontogeny of this behavior, e.g., is the sequence observed the first time an individual shoots, or is it assembled gradually over time with increasing experience?

\section{METHOD}

Captive archers will shoot for prey, and the probability of performing this act is strongest in fish that are hungry and have not shot for some time (Lüling, 1963). Our four archers were housed in a 120-liter aquarium. The fish were starved for 12 periods of $72 \mathrm{~h}$ each. After each period, they were presented with either a small cricket or a moth. The prey was suspended by a thread approximately $30 \mathrm{~cm}$ above the surface of the water for $30 \mathrm{~min}$ or until a shot was taken. The fish were allowed to consume prey that were "hit," and after the testing period they were fed to satiation.

\section{BEHAVIORS OBSERVED}

The fish went through a series of behaviors before attempting to shoot. Interobserver agreement, although not statistically determined, was very high

We thank David Chiszar and Larry Dill for helpful comments on an earlier draft of this paper. This paper is sponsored by Raymond $C$. Miles, who takes full editorial responsibility for its content. due to the fact that individual behaviors were very discrete. Prior to testing, the fish were inactive, remaining as a group on the bottom of the tank. Upon presentation of the prey, the following behaviors were performed:

\section{Orient (0)}

The fish oriented their bodies on a diagonal in the direction of the suspended prey.

\section{Swim (S)}

The fish swam to a point directly below the suspended prey, the eyes of the fish just about breaking the surface of the water (refraction of light by water does not appear to be a problem [Lüling, 1963]).

\section{Rotate Vertically (RV)}

When directly under the prey, the fish shifted its body vertically and extended its dorsal and pelvic fins, remaining in this position for usually $1-3 \mathrm{sec}$, sometimes the fish would RV after swimming and then begin swimming again and do a second $R V\left(R V_{2}\right.$ on Figure 1).

\section{Leap (L)}

The fish jumped out of the water, apparently attempting to get the suspended prey in this manner.

\section{Shoot $(\mathbf{S H})$}

The fish ejected a stream of water from its mouth in the direction of the suspended prey.

The tish were dull in coloration (silver-gray) while grouped at the bottom of the tank, but by the time they began rotating vertically (RV), black stripes on a silver background became well-defined.

\section{RESULTS}

Figure 1 shows the frequency of occurrence of the various actions making up a shooting sequence. When 


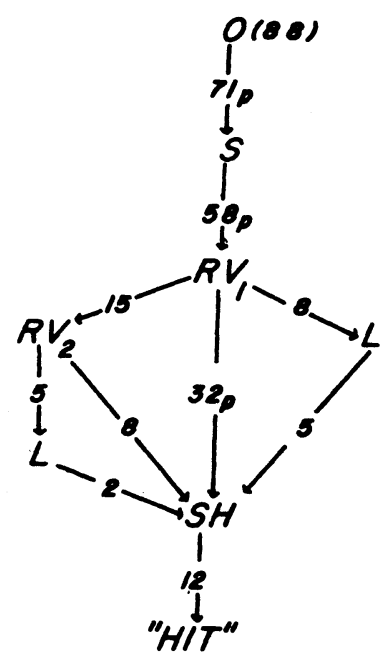

Figure 1. This figure shows the frequency of occurrence of the various actions making up a shooting sequence (orient, $\mathrm{O}$; swim, $\mathrm{S}$; first vertical rotation, $R V_{1}$; second vertical rotation, $R V_{2}$; leap, $L$; shoot, SH; the transition between the two acts connected by the arrow occurred significantly more frequently than expected by chance $[p<.001$; chi-square analysis $])$.

these data were analyzed in a transition matrix to determine whether or not two acts occurred in association with one another more frequently than expected by chance (e.g., Slater, 1973), we found significant $\mathrm{p}<.001$; chi-square analysis) transitions between $O$ and $S, S$ and $R V_{1}$, and $R V_{1}$ and $S H$, indicating that these actions followed one another more frequently than would have been expected by chance and more frequently than they followed other actions.

The fish shot and hit the insect 12/47 times $(25.5 \%)($ range $=14.3 \%-30.8 \%)$. Shooting $(\mathrm{SH})$ after leaping (L) was never successful, and leaping, too, never yielded food. When the prey was hit with the stream of water, we immediately cut the thread holding the insect and the insect fell into the tank and was immediately consumed by the fish which had done the shooting. No sharing of food was observed. After shooting, a fish would begin swimming quickly through the water in an undirected "hyperactive" manner, snapping its jaws at the sides of the tank and tossing its snout from side to side until it located the insect.

\section{DISCUSSION}

In nature, the force of the ejected stream of water might, in fact, be sufficient to dislodge an insect from a leaf or blade of grass by simply moving the surface on which the insect had alighted. Therefore, hitting the prey directly would not be necessary. Lüling (1963) noted that an archer can change the direction of the stream of water depending on the orientation of the prey. However, even if we counted all shots falling with a 5-cm radius as "hits," the success rate still would not have been greater than $35 \%$. Many of the shots were more than $15-20 \mathrm{~cm}$ off the mark, and the residual spray did not appear strong enough to move appreciably a leaf or blade of grass. L. M. Dill (personal communication) has observed that Toxotes chatareus rarely miss targets by more than a few centimeters. Predation success of $50 \%$ and more has been noted in other fish (e.g., Chiszar \& Windell, 1973).

The selective advantage conferred by shooting is difficult to assess. Lüling (1963) wrote that "spouting . . . can hardly have been a significant factor in the survival of the species or in selection and differentiation within the species." In support of this contention, it is known that not all archers in a captive population are shooters (Herald, 1965; personal observations), and those who do shoot appear to do so with limited accuracy, at least in $T$. jaculatrix. Aerial shooting is but one way by which archers and other shooting fish obtain food (Vierke, 1973), and shooting success in the field has yet to be studied.

\section{REFERENCES}

Alcock, J. The evolution of the use of tools by feeding animals. Evolution, 1972, 26, 464-473.

Chiszar, D., \& Windell, J. T. Predation by bluegill sunfish (Lepomis macrochirus Rafinesque) upon mealworm larvae (Tenebrio molitor). Animal Behaviour, 1973, 21, 536-543.

Herald, E. S. How accurate is the archer fish? Pacific Discovery, 1965, 9, 12-13.

LüLING, K. H. Morphologische-anatomische und histologische Untersuchungen am Auge des Schutzenfisches Toxotes jaculatrix nebst Bemerkungen zum Spuckgehaben. Zeitschrift für Morphologie und Oekologie der Tiere, 1958, 47, 529-610.

Lüling, K. H. The archer fish. Scientific American, 1963. 209, 100-109.

Slater, P. J. B. Describing sequences of behavior. In P.' P. G. Bateson \& P. H. Klopfer (Eds.), Perspectives in ethology. New York: Plenum Press, 1973.

Sмiтh, H. M. The archer fish. Natural History, 1938, 38, 3-11.

SмIтн, H. M. The fresh water fish of Siam, or Thailand. $U . S$. National Museum Bulletin, 1945, 188, 489-498.

Vierke, J. Das Wassersprucken der Artn Gattung Colisa (Pisces: Anabantidae). Bonner Zoologisch Beitrage, 1973, 24, $62-104$.

(Received for publication October 20, 1975.) 